\title{
Triggering Employee Motivation in Adverse Organizational Contexts: "Going the Extra Mile" while Holding Hands with Uncertainty?
}

\author{
Daniel Roque Gomes ${ }^{1}$ (Corresponding author), Vanda Asseiro $^{2} \&$ Neuza Ribeiro ${ }^{3}$ \\ ${ }^{1}$ Management for Sustainability Research Center - CIGS, School of Education (ESEC-IPC), Polytechnic Institute of \\ Coimbra, Praça Herois do Ultramar, 3030-329, Coimbra, Portugal \\ ${ }^{2}$ School of Education (ESEC-IPC), Polytechnic Institute of Coimbra, Praça Herois do Ultramar, 3030-329, Coimbra, \\ Portugal \\ ${ }^{3}$ Management for Sustainability Research Center - CIGS, School of Technology and Management, Polytechnic \\ Institute of Leiria, Morro do Lena - Alto do Vieira, 2411 - 901, Leiria, Portugal \\ Correspondence: Daniel Roque Gomes, Management for Sustainability Research Center - CIGS, School of \\ Education (ESEC-IPC), Polytechnic Institute of Coimbra, Praça Herois do Ultramar, 3030-329, Coimbra, Portugal. \\ Tel: 351-239-793-160. E-mail: drmgomes@esec.pt
}

Received: June 15, 2012

Accepted: December 5, 2012

Online Published: January 7, 2013

doi:10.5430/bmr.v2n1p41

URL: http://dx.doi.org/10.5430/bmr.v2n1p41

\begin{abstract}
Current Economic and Market Crisis have launched the debate concerning the role of the Human Resources (HR) in organizations. The up to this point strategic discourse concerning this management area seems to be in discussion, mainly due to the need of consistency between cost-cutting organizational strategies and a high pressure for Sustainable HR Management (HRM) practices. The ability of organizations to manage their HR indicators to deliver strategic differentiation is a critical concern of Sustainability in HR. Employee motivation is a core performance indicator in HRM, due to the strong association with productivity, absenteeism or turnover.

An issue deserving consideration is to understand how practitioners may motivate employees in current adverse economic contexts, as the existing knowledge surrounding employee motivation was fundamentally based on growing-based economic scenarios. The main objective of the present study is thus, to explorean answer to the question: how to predict employee motivation in organizations embedded in adverse contexts?

One hundred and ten employees from fifteen stores of an organization from a sector of a clothing brand consists the sample of our study. Participants voluntarily answered to a survey questionnaire that contained measures of the study variables. The hypotheses were tested using linear regression methodology.

Empirical evidences showed that the quality of the organization-employee relation seems to be more important than the quality of the job-employee relation to explain employee's motivation. In addition, results suggest that when the workers recognize fairness in the organization's procedures, they feel stronger support from the organization and this has the ability to motivate them.

The importance and significance of these results are discussed at theoretical and empirical levels, and we advance a set of recommendations to HR practitioners, in order to apply good employee's motivation practices.
\end{abstract}

Keywords: Employee's motivation, Prediction, Sustainability in HR

\section{Introduction}

When business and organizations are in discussion, it's easy to understand that there exists a wide amount of indicators that can significantly affect organizational performance. This assumption is mostly due to the advancements made in the last three decades, which are globally related to: (1) research developments; (2) economic characteristics and the ways how organizations are pressured to work in competitive business contexts.

Regarding the research developments, numerous scientific disciplines have made knowledge advancements regarding diversified matters of organizations' strategic management. Broadly, the subjects in discussion were related with the way how organizations deal with the internal and external consequences of competitive market dynamics, and manage them in an effective manner (Boselie, Dietz \& Boon, 2005). As such, based on this perspective, several specific aspects of strategic management have been largely discussed in research forums, such as: 
developing organizational outcomes (e.g. effectiveness); managing financial performance (e.g. value contribution); human resource management (e.g. employee training, employee recruitment and selection) (e.g. Barber, 1998; Gomes \& Neves, 2011). As research that investigates business and management never has fitted into a single discipline, the diversification of scientific fields concerning the strategic management issues is currently a quite wide issue (e.g. organizational psychology; communication management; marketing management).

An interesting way of categorizing all these research advancements and the nature of contributions to organizational management, is through the criteria of the levels of analysis. If following the organizational level of analysis, the issues under consideration are mostly related with organizational strategy and policies that can affect quality, production or efficacy indicators (eg. : Hyvonen, 2007). When following a group level of analysis, the focus is directed to group efficiency processes and contexts that affect, for instance, productivity indicators (eg. : Kerr \& Tindale, 2004). Lastly, if following an individual level of analysis, the worker is the focus of attention, and the indicators under scrutiny are deeply related to organizational climate perceptions that relate to organizational dynamics, such as job satisfaction, justice perception or employee motivation (eg.: Rotenberry \& Moberg, 2007).

Regarding the economic characteristics and the ways how organizations are pressured to work in competitive business contexts, during the last three decades, we have witnessed global economic developments that had the power to affect market dynamics in a very significant way (Boselie, Dietz \& Boon, 2005). Some of the most strongly representative features of these global economies relate with the high levels of competitiveness, the pressure for innovation or change, and more recently, the adversity of these characteristics when the European economic crisis came. It's in this particular adverse context that organizations are faced with the "survival rule": applying effective ways to distinguish from competing organizations, and manage all resources strategically and sustainably.

The employee is obviously not excluded from the "survival rule", as all business and management strategies depend, at least in minimal degree, on the employees, bringing light to the importance of the human resources in organizations. The key issue here is that, Human Resource Management (HRM) is consensually considered to be a management area able to bring strategic contributions to organizations (ex.: Baron \& Armstrong, 2007; Friedman, 2007). In part, this consensus was built with inputs from other research fields to Human Resources Management's Theory, such as organizational psychology, which mainly follows an individual level of analysis. As such, it is quite pertinent to consider HRM's specific contributions in the "survival rule" brought by competitive economies, and enlarged by current adverse business contexts. As the ongoing context is uncertain in terms of prospects of rapid resolution, it's very important to question the relation between the employee and the organization in such conditions.

One of the main indicators that relate with competitiveness is employee motivation, due to its association with issues such as productivity and performance (eg. : Katzell \& Thompson, 1990; Lewis, Goodman \& Fandt 1995; Sharbrough, 2006; Simms, 2007). It becomes crucial and with esteemed added-value, to understand how can entrepreneurs motivate employees, while facing with the strong uncertainty of current adverse business contexts. The issue deserves an additional consideration, in a time when organizations are pressured to be managed towards sustainability, and to nurture long-term compromises in their relation with publics and stakeholders. Managing organizations sustainably obviously pressures HRM, as the HR are the fundamental internal public of any sustainable organization. This study follows the individual level of analysis, and aims to explore an answer to the question: How to predict employee motivation in organizations embedded in adverse contexts?

The paper has three main sections: (1) Theory Review - in this section we will make a revision regarding the main theoretical trends that support the research question. We will start by discussing the role of Human Resource Management in the context of current economic and market pressures, and will move on to the subject of employee motivation to justify the relevance of our research question; (2) Method - in this section we will present the sample and procedure followed to provide empirical support to our research question, the measures and all the statistical procedures developed; (3) Results - in this section, we will present the results of our study, and explain their content and its bearing; (4) Discussion and Conclusion - in this section, we will provide a reflection regarding the bearing or our research and its implications for Theory and Practice.

\section{Human Resource Management and the employee-organization relationship in adverse contexts}

\subsection{Human Resource Managementand market pressures in perspective}

Market dynamics have always pressured organizations to know how to be empowered to deal with the complexity and challenges portraying the environments where they are embedded (Becker \& Gerhart, 1996; Ulrich, 1998). As such, managers and academics have always been concerned with identifying viable management areas to promote organizational performance. One of these areas is HRM, which is concerned with "effectively using the assets of 
human resources for the attainment of organizational goals and the continued viability and success of the organization" (Wright, Rowland \& Ferris, 1990, p.4). Especially since the late 80's, researchers and managers have realized that this is a strategic management area in any organization, as its activities happen as an inevitable consequenceof starting or growing an organization (Boxall, Purcell \& Wright, 2007).

The positive discourse and reasoning concerning the strategic properties of HRM was built based on evidences suggesting the strong impact of strategic HRM practices on workers' productivity, motivation and well-being in work locations (eg.: Parker, Wall \& Corderly, 2001). Consequently, HRM has become a main target of attention by managers and researchers, viewing it as a strategic path of investment for the challenges brought by global competitive markets (Rose \& Kumar, 2006; Friedman, 2007), and critical for organizational competitiveness (e.g.: Wright, Gardner, Moynihan \& Allen, 2005).

The last few couple of years, however, have brought high visibility to the word "uncertainty" in entrepreneurs, employees and academics' discourse. Due to the recent European global economic crisis, the ongoing economic context imposes a priority of costs reducing (cost-cutting strategies) and immediate organizational changes, forcing organizations to be more flexible. The way how organizations dealt with these austerity impositions have lead to a strong line of action over the restructuring of jobs, suppression or elimination of functions, or even, in extreme cases, through unemployment decisions on a significant scale. Consequently, reality seems to have brought a set of evidences that appear to dispute, the up to this point, widely accepted positive discourse associated with the investment on the human side of organizations.

The late 80's and early 90's positive vision of the human factor in organizations seems to be challenged nowadays, placing HRM in a somewhat paradox reality. On the one hand, HRM has not failed to deliver an added-value proposal to organizations and to management. We can see this perspective based on solid academic researches, and also, on the practitioners' positive discourse regarding the role of HR in organizations. Having the Resource Based Vision (RBV) (Barney, 1991) framework in mind, for example, the human capital has been clearly identified as a valid resource category for building competitive advantages. In addition, several empirical evidences have confirmed the link between HRM and competitiveness (eg.: Storey, 1995; Michaels, Hanfield-Jones \& Axelrod, 2001; Stavrou \& Brewster, 2005; Baron \& Armstrong, 2007). But on the other hand, while holding hands with this discourse, we have been witnessing, for instance, to organizational downsizings as a viable strategic path for obtaining competitiveness in global markets.

These contents, we believe, do not question the relevance of human resources in organizations, however, they show that HR practices need to deliver a set of contributions based on a renewed added-value promise: sustainability in HRM. The idea surrounding sustainability is widely related with the triple-bottom-line strategic guidance to organizational management, usually visible in Corporate Social Responsibility (CSR) programs. The adoption of CSR programs is a way for organizations to become actively engaged in sustainable development (Carroll \& Shabana, 2010), as it refers to "meet the needs of the present without compromising the ability of future generations to meet their own needs" (World Commission on Environment and Development, 1987, p.8).

Although sustainability is not a new subject in management, its extension to HRM issues is scarce (Thom \& Zaugg, 2004). According to Ehnert (2006), the idea over sustainability in HRM relates with the HR professionals' decision-making permanent tension between short-termed contributes to the organization and long-term organizational viability. This means that in the current economic context, HRM must be able to have a set of HRM practices bringing visible benefits to the organization (eg.: Wright \& Snell, 2005; Ehnert, 2009), such as, for instance, the ability to: act efficiently towards the problem of attracting highly qualified and talented HR (eg.: Gomes \& Neves, 2011); develop training programs carrying high transfer abilities to work locations (eg.: Carbery \& Garavan, 2005). As such, nowadays, HR managers are highly pressured to provide a strong contribute to the organization, based on the functions that relate to the way how the workers are attracted, managed, developed, appraised and maintained in the organization with high effectiveness levels.

According to this reasoning, the key-issue of sustainable HRM is to have efficient HR practices today in order to collect strategic differentiation tomorrow. The consequences of not doing so may range from lack of market share to downsizings or bankrupt scenarios. Following Ehnert's (2006) line of reasoning, one of the critical questions the literature linking sustainability and HRM asks is: how can HR executives manage future supply with qualified and motivated human resources? The question is of valuable importance, as the current economic scenario has brought increased visibility to the issue, notably, over the importance of the employee-organization relationship in adverse contexts, where organizations deal with extreme uncertainty. Delivering an answer to the question is thus, of high 
academic and practical level. Motivation is a critical element of this employee-organization relationship due to its nature and its content, and delivers a strong input over the way how organizations deal with the "survival rule".

\subsection{Employee Motivation in perspective}

Employee motivation is a long-lasting research subject on HRM and organizational psychology's remits of investigation. The attention surrounding the topic has presumably started in the 30's, and based on the first entrepreneurs' tacit findings that motivated employees are more productive ones. Since then, the knowledge concerning employee motivation has met several kinds of explanations and models. Currently, what we know about motivation invites us to consider it as the result of an interaction between the individual (eg.: values, beliefs, attributes) and a specific situation (eg.: context influences).

By definition, it refers to the desire to adopt high levels of personal effort justified by the achievement of organizational objectives, leading these efforts to the satisfaction of a particular individual need (eg.: Turner, 1995; Stipek, 1996). In this sense, motivation involves a set of three essential elements combining: (1) the effort or intensity of a certain impulse; (2) a specific need that will justify the effort; (3) an objective, or a particular purpose to be achieved (Scholl, 2002; Neves, 2002; Pina e Cunha, Rego, Campos e Cunha, Cabral-Cardoso, Marques \& Gomes, 2010). According to these elements, it's very easy to conceive why did this construct became prominent in HRM and organizational psychology literatures, namely, in what regards its relation to productivity (eg.: Mehta, Dubinsky \& Anderson, 2003; Davis \& Newstrom, 2004; Silverman, 2006; Kellerman, 2007). A retrospective analysis regarding the scientific study of motivation reveals a very rich field of research, built upon different Motivational Models, which provided answers regarding structural questions about motivation.

These models can be grouped following a Motivational Model's Taxonomy, based on the content criteria of the different studies concerning the subject: (1)Need-based - centered on the focus of motivation; (2)Process-based centered on how the motivation is expressed; (3)Result-based - centered on the why of the motivation(Neves, 2011; Pina e Cunha, Rego, Campos e Cunha \& Cabral-Cardoso, 2007). This taxonomy integrates general theories of motivation, but also organizational rooted theories, which are very focused on the explanation of the antecedents, mediators and moderators of employee motivation, and also its consequents. When the elements of these different proposals are in consideration, we become acquainted with different perspectives, shedding light on dissimilar, yet complementary aspects of the study of employee motivation, which can be analysed under three main criteria: its focus; their contributors; their predictors. (Note 1)

Regarding the focus, the need-based theories globally devote themselves to the analysis of the motives of human behaviour in organizations. These perspectives about motivation follow the assumption that employees have internal needs that represent a certain degree of energy towards behaviour (Neves, 2011). For this reason in particular, need-based theories usually place strong importance in the understanding of the employees' internal states. Among the most significant need-based theories, we can underline the Herzberg's Bi-factorial Theory (1966) and the Hackman and Oldham's Job Characteristics Model (1976).

The first one is a theoretical proposal that globally says that employee's motivations are regulated by two fundamental needs: (1) motivational factors/needs (intrinsic) - achievement, recognition for accomplishment, challenging work, increase responsibility, growth and development. ; (2) hygienic factors/ needs (extrinsic) - policies and administration, supervision, working conditions, interpersonal relations, money, status, and security. When these factors are attended, they are able to induce productivity and positive work attitudes. Consequently, the Bi-factorial Theory has made a solid contribute regarding the identification of motivation and satisfaction predictors, which influenced subsequent approaches, such as the Job Characteristics Model(JCM) (Hackman and Oldham, 1976).

JCM is a very comprehensive model concerning how the jobs are structured, defining that there are three psychological states that explain motivation, satisfaction or performance (in addition, other studies seem to confirm similar properties in results as commitment (Bhuian, Al-Shammari \& Jefri, 2001; Bhuian \& Menguc, 2002) or the attractiveness of the organization (Gomes \& Neves, 2010)). Essentially, the proposal contemplates the existence of five essential characteristics that structure the jobs: autonomy, feedback, skill variety, task identity, task significance. These characteristics will activate the following psychological states: (1) meaningfulness of work - arises from the variety, significance and identity of the task - and refers to the experience of the perceived meaning of work for the developer; (2) responsibility of the work - comes from autonomy - and refers to the experience of perceived responsibility in the performance of the function for the developer; (3) knowledge of outcomes - comes from feedback - and refers to the perceived experience that feedback inherent to the performance of the function provides to the developer. These different psychological states explain the motivation. 
From the point of view of their contribution, these need-based perspectives brought an important comprehension about the motivating properties inherent to the jobs, by establishing associations between job characteristics and motivation (ex.: Hackman \& Oldham, 1980). They have also contributed to clarify that the creation of desirable effects regarding employee's responses may come from the work itself (Pina e Cunha, et al., 2007). In addition, they have brought important insights regarding some practical applications, normally associated with setting rules for job design(ex.: Ganster \& Dodd, 1996; Boonzaier, Ficker \& Rust, 2000).

From the point of view of the predictors of motivation, the content perspective suggests that factors relating to working conditions, with the characteristics of the job, the safety of the work post, or benefits of the function are valid elements for determining employee motivation (eg. Hackman \& Oldham, 1980; Hersey \& Blanchard, 1986; Houkes, Janssen, de Jonge \& Nijhuis, 2001; Parker, Wall \& Cordery, 2001; Houkes, 2002). So, these perspectives suggest very clearly that the job characteristics and the structure of jobs may have properties that activate the employee's motivation, which emphasizes the importance of the individual-job relation for this purpose.

Concerning the process-based theories, from its focus point of view, they seek to understand and to systematize the regularities of motives and the fundamental needs that constitute the energy that grounds the behaviour (Neves, 2011). It assumes that there are individual differences that constrain the development of motivation, accepting that not all employees are motivated by the same way. In this sense, these perspectives seek to understand the structure of the fundamental processes, according to which, the motivation is developed (Pina e Cunha, et al., 2007). Its focus is on the motivational process and in the factors that influence it. As such, this process is usually investigated using additive and/or multiplicative models, aiming to understand the mediational and/or moderation effects that structure or affect the motivational processes.

From the point of view of its contribution, these process-based perspectives brought an important reading of motivation as a result of the individual-organization relation (eg.: Tremblay, Sire \& Balkin, 2000). They have also contributed to clarify the prediction of motivation that results from the inter-individual's comparison, notably with respect to ratios that are established and compared, between inputs and outputs. As such, process-based theories have established that motivation has a larger set of predictors, namely, the ones that relate to the quality of the individual-organization's relation.

One of the most fluent process-based motivational perspectives refers to the Equity Theory (ET) (Adams, 1965), whose orientations gave the foundations of research in organizational justice (eg.: Thibaut and Walker, 1975; Colquitt, Conlon, Porter \& Ng, 2001). The ET states that employees experience discrepancies when comparing their gains and their efforts with gains and efforts of the others employees in reference (Neves, 2011; Pina e Cunha, et al., 2007). Equity comes from this comparison and the evaluationof inputs and outputs of individuals in comparison. One of the strongest consequences of equity in organizations is employee motivation. Another interesting process-based motivational theory is the Expectancy Theory (Vroom, 1964). The proposal has a cognitive vision about motivation, assuming that each person is a rational decider about the effort that is willing to deliver in a work situation. In organizational contexts, the theory is based on the idea that employees believe there are relationships between the work efforts, the performance that they can achieve resulting from those efforts, and the compensations they may receive as a natural consequence of their efforts and performance (Lunenburg, 2011). The individual establishes a cognitive reasoning regarding the expectation of the results (relation between efforts and outcome), the valence (appreciation about what the organization offers) and instrumentality (need-level performance to achieve desired result). In sum, this perspective about motivation depends on the assurance of the conditionsthat were described above. Consequently, motivation results from the following multiplicative equation: motivation $=\mathrm{f}$ (expectancy $\mathrm{x}$ instrumentality x valence) (Neves, 2011; Lunenburg, 2011).

From the point of view of the predictors of motivation, the process-based motivational perspectives seem to reinforce the prediction of motivation using job determinants. From a critical viewpoint, the job factors appear to have some prevalence in explaining employee's motivation. However, the process-base perspective also points evidences that invite to consider the importance of the quality of the individual-organization relation. Thus, the employee's self-efficacy perception, the compensation provided by the organization in accordance with the employee's efforts, as well as organizational justice perceptions, the enrichment of skills and organizational policies, seem to be valid employee's motivation predictors (eg.: Lawler, 1994; Shore \& Shore, 1995; Darolia, Darolia \& Kumari, 2010).

Complementarily, the importance of the individual - organization relation in the prediction of motivation is reinforced by two alternative perspectives: the Social Exchange and the Psychological Contract (Aselage \& Eisenberg, 2003). The first one is a psychological and sociological driven perspective, which globally states that human relationships are based upon a cost-benefit analysis, viewing behaviour as a result anequitable exchange 
process (Emerson, 1962). In organizational contexts, when the costs and benefits are balanced in the individual-organizational relationship, then that relationship is equitable. As such, employee motivation may be seen as a result of the quality of the exchange results the organization provides to the individual, reinforcing the relevance of the individual-organization relation for predicting motivation.

As for the Psychological Contract perspective, it relates to the dynamical relationship regarding the informal obligations between an organization and its employees, having the ability to affect employee's behaviour (Rousseau, 1995; Coyle-Shapiro, J., 2002). Regarding its content, it involves the employee's beliefs concerning the nature of the reciprocal and dynamic obligations maintained in the employee-organization relationship (Shore \& Tetrick, 1994). Therefore, having the psychological contract perspective in mind, it's quite easy to conceive motivation as a natural occurring result of the employee-organization positive dynamical relationship. With effect, both the social exchange and the psychological contract perspectives are quite pertinent when discussing some empirical findings pointing for the importance of the organizational-employee relationship (the perceived support-motivation positive association (eg.: Aselage \& Eisenberg, 2003); the quality of affiliation between individual and organization - affective organizational commitment-motivation positive association (eg.: Eby, Freemam, Rush \& Lance, 1999); the working environments perspective: the organizational climate-motivation positive association (eg.: Mahal, 2009)).

An integrated analysis of all the above mentioned theoretical perspectives seems to suggest that the job-related and organizational-related factors are valid predictors of motivation. An argument worthy of mentioning refers to the fact that existing knowledge on employee's motivation prediction is solid, when properly considered the consistency of available empirical evidences. However, an important element deserving consideration refers to the fact that these evidences wereglobally anchoredin growing-based economical contexts, which have different characteristics than the ones characterizing the current cost-cutting economical contexts with high pressure for sustainable HRM practices. In this sense, we believe to be of added-value to explore if these perspectives are up-to-date when considering the austerity impositions in current organizational scenarios. So, an interesting way of evaluating this issue in particular should be about establishing a comparison betweenthe most commonly referred employee's motivation predictors arising from existing literature regarding their nature: (1) the job-employee relationship; (2) the organizational-employee relationship. Thus, we consider relevant to perform an exploratory analysis aiming to evaluate the compared importance of job-related and organizational-related predictors of employee motivation. To do so, will bring an interesting academic contribution of this paper to existing research. Consequently, the first exploratory hypothesis that comes from the discussion that was presented is: What is the nature of the predictors that better explain employee's motivation in current adverse contexts?

In addition, we have considered that explaining employee's motivation through simple and direct relations (as the ones firstly proposed) is surely a restrictive way of understanding the deepness of the indicator. As mentioned earlier, motivation can be explained by a generous variety of approaches. As such, one that immediately occurred in order to gain added understanding of this issue is exploring in what way may employee's motivation be explained using an additive/process-based approach, that is to say, assuming that employee's motivation may be the result of a distal process, explained by the influence of mediator variables. In accordance with this reasoning, two additional exploratory questions were posited: May employee motivation be explained by a process-based model? In such case, which factors intervene in the employee's motivational process?

\section{Method}

\subsection{Sample and Procedure}

This convenience sample integrates 110 employees from 15 stores of an organization from a sector of a clothing brand. The sample consists mostly of female participants (72.4\%), aged mainly between 26-30 years (54\%). Regarding antiquity in the organization, $32 \%$ of the participants are working with the organization for less than 2 years and 24\% between 2 and 10 years. Each participant received a survey integrating the measures of the study variables. The instructions informed them that they were participating in a survey whose aim was to understand what they most valued in an organization. The construction of the questionnaire obeyed to several criteria in order to minimize and control the impact of potential systematic errors according to Podsakoff, Mackenzie, Lee and Podsakoff's (2003) suggestions.

Regarding the procedure, the Human Resources Management Central Services sent a copy of the instrument to a manager of each store to ensure the application and collection of the data. Each store manager has guaranteed an adequate space for the data collecting, and assured that the participants understood what was asked when filling the survey. In addition, all the instructions regarding the filling of the questionnaire and the purpose of the study were also written on the cover of the instrument's sheet. 


\subsection{Measures}

Unless otherwise indicated, the items were measured using a seven-point scale ranging from $1=$ Strongly Disagree to $7=$ Strongly Agree.

Affective Organizational Commitment: Defined as "the emotional connection, and of identification and involvement" established between employees and the organization (Meyer \& Allen 1997, p. 11). We've adapted Allen and Meyer's (1996) scale to measure organization affective commitment. The scale consists of six items (eg.: "I do not feel a great meaning in belonging to this organization").

Procedural Justice: Defined as the "fairness of the procedures used on determination of the rewards received by employees" (Caetano \& Vala, 1999, p.76). The indicator used was based on Caetano and Vala (1999) for measuring this variable. The scale consists of four items (eg.: "The way that supervision makes decisions about work in my service is fair").

Perceived Organizational Support: Defined as an employee's perception about the support and the concern of the organization about itself and its well-being in their work context (Allen, Shore \& Griffeth, 2003). Perceived support was assessed using a reduced scale of three items adapted from Eisenberger, Huntington, Hutchinson, and Sowa (1986) (eg "This organization considers the results of my work").

Motivation: To measure motivation with the organization we've adapted Patchen's (1970) scale, consisting of four items (eg.: "I am very motivated to work in this organization").

Job Characteristics. Ten items from Hackman and Oldham (1976) Job Characteristics Model were used to measure job characteristics. Two items were used to measure autonomy, feedback, task variety, task identity and task significance. Items include: "This job would allow strong autonomy and independence in the organization of activities to perform", "The impact of my work requires learning new techniques over the years". A five-points Likert scale was used to measure all the Job Characteristics variables ranging from $1=$ Strongly Disagree to $5=$ Strongly Agree

\section{Results}

To ensure the reliability of the measurements, it was used as reference the Cronbach's Alpha coefficient, assuming as criteria for the construction of composite variable values equal or superior 0.70 (Nunnally, 1978). We have also tested for the robustness of data errors introduced by the common method variance. For that, we've applied the Harman Test. According to the propositions of the test, if a significant amount of common method bias exists in data, then a factor analysis (unrotated solution) of all the variables is expected to give rise to a single factor accounting for the large majority of the variance (Podsakoff, Mackenzie, Lee \& Podsakoff, 2003). Our results revealed that the data are in fact robust to such errors.

Table 1 shows the correlation matrix as well as the means, standard deviations, inter-item correlations, and reliabilities for all variables. The multi-item scale reliabilities were all very good and the inter-item correlations (for variables composed with only two items) all correlated at $p \leq .01$.

Table 1. Descriptive Statistics and Correlation Matrix

\begin{tabular}{llllllllllll}
\hline & Mean & SD & $\mathbf{1}$ & $\mathbf{2}$ & $\mathbf{3}$ & $\mathbf{4}$ & $\mathbf{5}$ & $\mathbf{6}$ & $\mathbf{7}$ & $\mathbf{8}$ & $\mathbf{9}$ \\
\hline 1. Autonomy & $3,24^{(2)}$ & 1,06 & $.54^{(b)}$ & & & & & & & & \\
2. Skill variety & $3,59^{(2)}$ & 0,92 &, $368^{* *}$ & $.42^{(\mathrm{b})}$ & & & & & & & \\
3. Feedback & $2,71^{(2)}$ & 1,02 &, $201^{*}$ &, 026 & $.37^{(b)}$ & & & & & & \\
4. Task meaning & $2,65^{(2)}$ & 1,01 &, $503^{* *}$ &, $289^{* *}$ &, $372^{* *}$ & $.45^{(b)}$ & & & & & \\
5. Task identity & $3,48^{(2)}$ & 0,77 &, $370^{* *}$ &, $633^{* *}$ &, $204^{*}$ &, $382^{* *}$ & $.39^{(b)}$ & & & & \\
6. Organizational support & $2,99^{(1)}$ & 1,46 &, 174 &,- 005 &, $534^{* *}$ &, $213^{*}$ &, 101 & $.73^{(a)}$ & & & \\
7. Procedural Justice & $3,60^{(1)}$ & 1,30 &, 098 &,$- 206^{*}$ &, $449^{* *}$ &, 006 &,- 123 &, $614^{* *}$ & $.72^{(a)}$ & & \\
8. Affective commitment & $3,97^{(1)}$ & 0,77 &, $271^{* *}$ &, $199^{*}$ &, $254^{* *}$ &, $340^{* *}$ &, $232^{*}$ &, $372^{* *}$ &, 188 & $.78^{(a)}$ & \\
9. Motivation & $3,81^{(1)}$ & $1,12,132$ &,- 140 & $\mathbf{, 3 9 4}^{* *}$ &, 035 &,- 038 & $\mathbf{, 6 8 9}^{* *}$ & $\mathbf{6 9 9}$ &, $202^{*}$ & $.70^{(a)}$ \\
\hline
\end{tabular}

** All variables correlated to $\mathrm{p} \leq .01 / *$ All variables correlated to $\mathrm{p} \leq .05$ 
(1) Applied Likert scale of 7 points / (2) Applied Likert scale of 5 points

(a) Values of Cronbach's Alpha

(b) Values of significant inter-item correlation $\mathrm{p} \leq .01$

Results shown above revealed that under the point of view of the variables expressing the relation job-employee relation, only the task feedback $(r=, 39)$ is significantly and positively associated with motivation. None of the other variables related to job characteristics showed a similar association. In contrast, regarding the set of variables that expressing the organization-employee relation, they have all expressed positive and significant association with motivation. We would like to stress out the relation with procedural justice $(r=, 699)$ and organizational support $(r=$, 689 ) as the strongest ones.

According to these results, the quality of the organization-employee relation seems to be more important than the quality of the job-employee relation to explain employee's motivation. As such, we became interested in evaluating the relative importance of each factor regarding their motivation prediction's abilities. So, in order to quantify and to understand the magnitude of these relations, we proceeded to an analysis of the compared importance of the variables significantly correlated with motivation through the use of Regressions Method. Regarding the procedure, we have loaded into a single regression all composite variables that showed significant and positive association with motivation. Through this procedure it is possible to identify which job-employee and organization-employee factors are the most important predictors of motivation. In addition, it also enables to control eventual spurious effects from the relation between the variables, not accessible in the previous correlation analyzes. Table 2 shows the procedure described above.

Table 2. Evaluation of the compared importance of the predictive factors

\begin{tabular}{|c|c|c|c|c|c|c|c|c|c|c|}
\hline & \multicolumn{2}{|c|}{$\begin{array}{l}\text { Non-standard } \\
\text { coefficients }\end{array}$} & \multirow{2}{*}{\begin{tabular}{|l|}
$\begin{array}{l}\text { Standard } \\
\text { coefficients }\end{array}$ \\
$\beta$
\end{tabular}} & \multirow[b]{2}{*}{$\mathrm{T}$} & \multirow[b]{2}{*}{ Sig. } & \multicolumn{3}{|c|}{ Correlations } & \multicolumn{2}{|c|}{$\begin{array}{l}\text { Collinearity } \\
\text { statistics }\end{array}$} \\
\hline & $B$ & $\begin{array}{l}\text { Std. } \\
\text { Error }\end{array}$ & & & & $\begin{array}{l}\text { Zero- } \\
\text { order }\end{array}$ & Partial & Part & Tol. & VIF \\
\hline Task Feedback &,- 013 &, 097 &,- 011 &,- 140 & 889 & 418 &,- 014 &,- 009 & 674 & 1,484 \\
\hline Organizational Support &, 364 &, 079 & 423 & 4,613 &, 000 &, 682 &, 422 & 297 & 494 & 2,026 \\
\hline Procedural Justice &, 369 &, 068 & 449 & 5,421 &, 000 &, 697 & 480 & 349 & 605 & 1,652 \\
\hline Affective commitment &,- 018 &, 076 &,- 017 &,- 238 &, 812 &, 218 &,- 024 &,- 015 & 834 & 1,199 \\
\hline
\end{tabular}

\section{Note: Dependent variable: Motivation}

Results showed that once the influence of the variables between each other was controlled, only the organizational $\underline{\operatorname{support}}(\beta=, 423 ; p<.01)$ and procedural justice $(\beta=, 449 ; p<.01)$ variables remained in a significant relation with motivation. It is also possible to see that affective organizational commitment $(\beta=-, 017 ; p>.05)$ and task feedback $(\beta=-, 011 ; p>.05)$ had no significant relation with motivation, not having significant predictive capacity. These results seem to indicate that participants give value to the degree and type of accompaniment that the organization provides and dedicates as well as the fairness of the procedures that applies in their management. The way how the organization shows dedication, accompaniment and concern regarding the employees, as well as the way it stimulates fairness procedures that arise from work situations seem to be important to determine their motivation.

Regarding this study's first hypothesis, these results seem to indicate that motivation is better explained from the quality of the organization-employee relation, relegating to second place the job-employee relation. As such, the nature of the predictors that better explain employee's motivation in current adverse contexts seem to be the organizational ones. Once this first exploratory hypothesis became clearer, we've immediately turned our attention towards the interest of understanding if employee's motivation results from an indirect relation, and with it, answering to this study's second hypothesis.

Based on our previous results, we've proposed that the factors intervening in the employee's motivational process would be the ones that previously shown to have good predictive abilities over motivation (organizational-employee 
variables: organizational support; procedural justice). Along with this reasoning, based on the psychological contract and the social exchange theory perspectives, we believe that whenever organizations foster fair procedures, employees will naturally feel supported and this may explain their motivation. As such, organizational support (mediator variable) should be the result of perceived organizational justice (predictor variable), and this process will predict employee's motivation (dependant variable). This proposal will allow testing the study's third hypothesis.

We followed Baron and Kenny's (1986) procedure (Note 2) to test this mediation hypothesis. First, we verified that organizational support and procedural justice (step one) were positively related $(\beta=, 614 ; p<.01)$ and procedural justice and motivation (step two) were also positively related $\left(\beta=, 766 ; p<.01 ; R^{2}\right.$ Adjust. $\left.=, 582\right)$. When controlling organizational support (model 2; table 3 ) in the relation between procedural justice and motivation (step three), the effect of procedural on motivation became weaker $(\beta=766 p<0.001 ; \beta=599 / \mathrm{p}<0.001)$, and the effect of organizational support on motivation was positive and significant $\left(\beta=, 258 ; p<.01 ; R^{2}\right.$ Adjust.=,627) (Model 1 - Model 2:Sig. F Change $=, 002$ ). Table 3 shows the results of the above mentioned procedure and hypothesis.

Table 3. Mediation analysis

\begin{tabular}{|c|c|c|c|c|c|c|c|c|}
\hline \multirow[b]{2}{*}{ Model } & \multicolumn{2}{|c|}{$\begin{array}{l}\text { Unstandardized } \\
\text { Coefficients }\end{array}$} & \multirow{2}{*}{\begin{tabular}{|l}
$\begin{array}{l}\text { Standardized } \\
\text { Coefficients }\end{array}$ \\
Beta
\end{tabular}} & \multirow[b]{2}{*}{$t$} & \multirow[b]{2}{*}{ Sig. } & \multicolumn{3}{|c|}{ Correlations } \\
\hline & $B$ & $\begin{array}{l}\text { Std. } \\
\text { Error }\end{array}$ & & & & $\begin{array}{l}\text { Zero-or } \\
\text { der }\end{array}$ & Partial & Part \\
\hline 1 Procedural Justice & 666 &, 056 &, 766 & 11,958 &, 000 &, 766 &, 766 &, 766 \\
\hline 2 Procedural Justice &, 521 &, 070 & ,599 & 7,436 &, 000 &, 766 &, 597 & 456 \\
\hline Organizational Support & 202 &, 063 & .258 & 3,201 &, 002 & 646 &, 305 &, 196 \\
\hline
\end{tabular}

Note: Dependent Variable: Motivation

Based on these results, there is evidence of a partial and significant mediation effect, seeming that fairness procedures have strong and direct predictive abilities over motivation. In addition, results suggest that when the workers recognize fairness in the organization's procedures, they feel stronger support from the organization and this has the ability to motivate them. In addition, we've also tested these results using SOBEL Test (Sobel, 1982). This is a very insightful test to understand mediation results as it accesses the indirect effects in a more direct way, as it is based on the following equation: $z$-value $=a^{*} b / \mathrm{SQRT}\left(b^{2}{ }^{2} s_{\mathrm{a}}{ }^{2}+a^{2}{ }^{2} s_{\mathrm{b}}{ }^{2}\right)$. The Sobel test statistic results were: $\mathrm{z}=$ 6.32963797 (One-tailed and Two-tailed probability: $p=0,000$ ), confirming the existence of the mediation effect. These results provide answer to the study's second and third hypothesis.

\section{Discussion and Conclusions}

Organizations in current global economic scenarios are highly pressured to be competitive in the way how innovation or change is performed, business opportunities are identified or how human resources management is developed. The issue of competitiveness in management has always been fundamental, but has gained new grounds, especially in the Euro Zone, for the past few years. When the European Economic crisis came, organizations were rapidly faced with serious business and management conditions, forcing them to make management decisions in order to maintain their viability in a market scenario where the "survival rule" is exceedingly visible. This issue has gained added visibility and interest in a time when sustainability is viewed as a strategic focus of competitive organizations.

As the employees are included in the ways how organizations manage their relationships with markets, we have focused our attention to the role of HRM in this highly constrained economic scenario, as it's a management area able to bring strategic differentiation (eg.: Baron \& Armstrong, 2007). One of the nuclear HR indicators is employee motivation, due to its association with productivity and performance (eg.: Simms, 2007). As such, in a time where organizations are heavily pressured to be sustainable, competitive and effective, it's very up-to-date to understand how can organizations motivate their employees when uncertainty is a key characteristic of current adverse business contexts. We believe that adressing these issues would be of esteemed academic value. Based on this reasoning, we've proposed to explore an answer to the following research question: How to predict employee motivation in organizations embedded in adverse contexts?

Based on our literature revision, notably, on need-based and process-based motivational theories, as well as the psychological contract and social exchange perspectives, we have considered that both the job-employee and the organization-employee relations are important predictors of employee motivation. Through this simple conclusion, it 
seemed relevant to question in what extension these very same predictors have a similar predictive abilities, in an organization currently struggling against this adverse business context. For this reason, we have developed our data analysis following two main exploratory purposes: (1) establishing a comparison between the most commonly referred employee's motivation predictors suggested by the literature: the job-employee relationship; the organizational-employee relationship.; (2) in what way may employee's motivation be explained using an additive/process-based approach, notably, explained by the influence of a mediator variable.

Regarding the first exploratory purpose, the reading of our conclusions has invited us to consider that, contrarily to what seemed to emerge from existing literature, the organization-employee relation was the most important for employee motivation prediction. We believe that this result is interesting to analyze in particular. Although it's consistent with the perspectives based on determining motivation through the organizational-employee relation, it ends up rejecting the importance that has been attributed by several theoretical perspectives to the importance of job-related factors for employee's motivation purposes. As such, our results seem to be carrying signs that invite not to consider the structure of the functions as a source of motivation. Instead, it seems that the way how organizations attend the employees and how the work procedures are based on justice criteria is critical for determining employee's motivation (much in line, with the social exchange and psychological contract perspectives of motivation).

In addition, and regarding our second exploratory purpose, we have tried to understand employee's motivation in an additive/process-based approach, in order to gain added comprehension regarding this issue in particular. Our results have evidenced a meditational effect of perceived support in the relation between organizational procedural justice and employee motivation. These results suggest that the recognition of fairness procedures in the way how organizations manage their human resources leads to perceived support, which explains motivation. Although, from our data, it's not possible to establish causality between outcomes and the adverse economic environments, it's interesting to read these indicatorsin several levels: theoretical, empirical and practical.

At a theoretical level, we've tried to systematize and bring together a theoretical analysis of a set of contributions of various approaches regarding employee's motivation, and their prediction. Accordingly, we have established a comparative analysis integrating the contribution of process-based, need-based, and also, using the psychological contract and the social exchange perspectives applied to motivation's remit of analysis. We have added the issue of to today's economic and financial reality, and have discussed the influence it can bring to the way how human resources management is performed in organizations under an adverse economic scenario, and in what way this may influence employee's motivation.

Empirically, we would like to emphasize that our methodological and empirical procedure were carefully considered under the exploratory purposes around the study. It is important to underline that several methodological procedures were carefully taken into consideration in order to assure the validity of our data and results, namely, the control of the error variance of the common method, by the testing of Harman. The results obtained during this study have allowed us to compare the importance of predictors of the job-employee and organization-employeerelation with motivation. The results have evidenced the prevalence of organization-employee relation regarding employee's motivation.

At a practical level, our results seem to support that the job design and the solution of re-structuring functions seems to have no effects on employee's motivation in organizations working in adverse economic environments. It seems to be more crucial that organizations invest their time in finding correct ways of showing attention and have fairness management procedures regarding the way how employees are managed. This seems to be an effective employees' motivational strategy to be followed by managers. It seems important that human resource managers are aware that the way how the organization communicates that it is committed to employees and is concerned about having fair work procedures has strong motivation effects. This may very well imply that that internal communication should be considered on a global HR strategy for the purpose of employee's motivation. A good coordination between internal communication and HR professionals appears to constitute a solid line of action. Internal Communication professionals, should develop procedures based on the development of the parameter of the role (axes of cohesion and confront) (see Henriet and Boneu (1990) for additional information regarding the content of the internal communication axis) of employees in the organization, as it seems to be the most appropriate area of development.

The reading of these indications and final considerations should be made with a proper understanding of its limitations, as well as a set of recommendations regarding prospective research following similar purposes. The first limitation that we would like to stress out related with the fact that our model of analysis is recursive, as it was theoretically established. As such, the directionality between variables that we've presented were theoretically driven, and tested using a correlation design, which impedes assuming causality. As such, we believe that a longitudinal 
character model would allow resolving the issues related to the causal effects of financial and economic crisis regarding the relation between employee's motivation predictors.

We also believe that future research should follow in a deeper way the fundaments arising from the Social Change and the Psychological Contract perspectives. They have showed strong applicability to understand employee's motivation using organizational-employee predictors in organizations currently working in strongly constrained economic realities. Additionally and especially based on the empirical grounds of our study, we think that a confirmatory study using the same purposes of analysis that we've carried out is surely welcomed. A very interesting complementary model of analysis regarding this study would be of testing the existence of a moderating effect of economic crisis perception over the mediational effect of perceived support in the relation between procedural justice and employee's motivation. This would be an empirically rich study, as it would be based on a testing a moderated-mediation effect (Note 3 ) which is unusual in business and management studies.

\section{References}

Adams, J.S. (1965). Inequity in social exchange. In L. Berkowitz (Ed.), Advances in experimental social psychology (Vol. 2, pp. 267-299). New York: Academic Press.

Allen, N. J. \& Meyer, J. P. (1996). Affective, continuance and normative commitment to the organization: An examination of construct validity. Journal of VocationalBehaviour, Vol. 49, 252-276. http://dx.doi.org/10.1006/jvbe.1996.0043

Allen, D. G., Shore, L. M. \& Griffeth, R. W. (2003). The role of perceived organizational support and supportive human resource practices in the turnover process. Journal of Management, Vol. 29, 99-118. http://dx.doi.org/10.1177/014920630302900107

Aselage, J., \& Eisenberger, R. (2003). Perceived organizational support and psychological contracts: A theoretical integration. Journal of Organizational Behavior, Vol. 24, 491-509. http://dx.doi.org/10.1002/job.211

Barber, A. E. (1998). Recruiting employees: Individual and organizational perspectives. Thousand Oaks, CA: Sage Publications.

Baron, R. M., and Kenny D. A. (1986). "Moderator-Mediator Variables Distinction in Social Psychological Research: Conceptual, Strategic, and Statistical Considerations", Journal of Personality and Social Psychology, Vol. 51 (6), 1173-82. http://dx.doi.org/10.1037/0022-3514.51.6.1173

Baron, A., Armstrong, M. (2007). Human Capital Management: Achieving Added Value Through People. London and Philadelphia: Kogan page.

Becker, B., \& Gerhart, B. (1996). The impact of human resource management on organizational performance: progress and prospects, Academy of Management, Vol. 39 (4), 779-801. http://dx.doi.org/10.2307/256712

Bhuian, S. N., Al-shammari, E. S., \& Jefri, O. A. (2001). Work-related attitudes and job characteristics of expatriates in Saudi Arabia. Thunderbird International Business Review, Vol. 43, 21-31. http://dx.doi.org/10.1002/1520-6874(200101/02)43:1<21::AID-TIE3>3.0.CO;2-B

Bhuain, S. N. \& Menguc, B. (2002). "An extension and evaluation of job characteristics, organizational commitment, and job satisfaction in an expatriate, guest worker, Sales setting", The Journal of Personal Selling and Sales Management, Vol. 22 No 1, pp. 1-11.

Boonzaier, B., Ficker, B., Rust, B. (2000). A Review of Research on the Job Characteristics Model and the Attendant Job Diagnostic Survey. South African Journal of BusinessManagemen, Vol.32 (1), 11 - 34.

Boselie, P., Dietz, G. Boon, C. (2005). "Commonalities and Contradictions in HRM and Performance Research", Human Resource Management Journal, Vol. 15, No. 3, 6794. http://dx.doi.org/10.1111/j.1748-8583.2005.tb00154.x

Boxall, P., Purcell, J., Wright, P. (2007). 'The Oxford Handbook of Human Resource Management', Oxford: Oxford University Press, 658pp.

Caetano. A., e Vala. J. (1999). "Efeitos da justiça organizacional percebida sobre a satisfação no trabalho e as opções comportamentais". Psicologia 13, 1/2: 75 - 84.

Carbery, R., e Garavan, T. N. (2005). Organizational restructuring and downsizing: Issues related to learning, training and employability of survivors. Journal of European Industrial Training, Vol. 29 (6), 488-508. http://dx.doi.org/10.1108/03090590510610272 
Carroll, A.B., and Shabana, K.M. (2010). "The business case for corporate social responsibility: a review of concepts, research and practice", International Journal of Management Reviews, Vol. 12, No. 1, pp. 85-105. http://dx.doi.org/10.1111/j.1468-2370.2009.00275.x

Colquitt, J. A., Conlon, D. E., Wesson, M.J., Porter, C., Ng, K.Y. (2001). Justice at theMillennium: A meta-analytic review of 25 years of organizational justice research. Journal of Applied Psychology, Vol. 86 (3), 425-445. http://dx.doi.org/10.1037/0021-9010.86.3.425

Coyle-Shapiro, J. (2002). A psychological contract perspective on organizational citizenship behavior. Journal of Organizational Behavior, Vol. 23, 927-946. http://dx.doi.org/10.1002/job.173

Darolia, C.R., Kumari, P., \& Darolia, S. (2010). Perceived Organizational Support, Work Motivation, and Organizational Commitment as determinants of Job Performance. Journalof the Indian Academy of Applied Psychology, January 2010, Vol. 36, No.1, 69-78.

Davis, K., Newstrom, J. W. (2004). Comportamento humano no trabalho: uma abordagem organizacional - volume 2, 3. ed. São Paulo: Pioneira.

Eby, L., Freemam, D., Rush, M. \& Lance, C. (1999). Motivational Bases of affective organizational commitment: A partial test of an integrative theoretical model. Journal of Occupational and Organizational Psychology,Vol.72, 463-483. http://dx.doi.org/10.1348/096317999166798

Ehnert, I. (2006). 'Sustainability Issues in Human Resource Management: Linkages, theoretical approaches, and outlines for an emerging field'. Paper prepared for 21st EIASM SHRM Workshop, Aston, Birmingham, March 28th-29th, 2006.

Ehnert, I. (2009). Sustainable human resource management: a conceptual and exploratory analysis from a paradox perspective. Contributions to management science, Heidelberg, Physica, Springer-Verlag.

Emerson, R. (1962). Power-Dependence Relations. American Sociological Review, Vol. 27(1), 31-41. http://dx.doi.org/10.2307/2089716

Eisenberger, R., Huntington, R., Hutchinson, S., \& Sowa, D. (1986). Perceive Organizational Support. Journal of Applied Psychology, Vol. 71, 500-507. http://dx.doi.org/10.1037/0021-9010.71.3.500

Friedman, G. (2007). The embedded corporation: Corporate governance and employment relations in Japan and the United States, Labour history Journal, Vol. 48,252-254

Ganster, D.C. \& Dodd, N.G. (1996). The interactive effects of variety, autonomy, and feedback on attitudes and $\begin{array}{llllll}\text { performance. Journal of Organizational Behavior, } & \text { Vol. } & \text { 17, } & \text { 329-347. }\end{array}$ http://dx.doi.org/10.1002/(SICI)1099-1379(199607)17:4<329::AID-JOB754>3.0.CO;2-B

Gomes, D. \& Neves, J. (2010). Applicants' prior experiences influence organizational attractiveness prediction?. Management Research, Vol. 8, pp. 203-220.

Gomes, D., \& Neves, J. (2011). "Organizational attractiveness and prospective applicant's intentions to apply. “Personnel Review, Vol. 40, 6: 684 - 689. http://dx.doi.org/10.1108/00483481111169634

Hackman, J. R. \& Oldham, G.R. (1976). Motivation through the design of work:Test of a theory. Organizational Behavior and Human Performance, Vol. 16, 250-279. http://dx.doi.org/10.1016/0030-5073(76)90016-7

Hackman, J. R. \& Oldham, G.R. (1980). Work Redesign, New York: Addison-Wesley Publishing Company.

HenrietB., \& Boneu F. (1990). Audit de la communication interne. Paris: Les Editions de l'Organisation.

Hersey, P \& Blanchard, K. (1986). Psicologia para administradores: teoria e as técnicas da liderança situacional. São Paulo: Epu.

Herzberg, F. (1966). Work and the nature of man. Cleveland, OH: World Publishing Company.

Houkes, I. (2002). "Work and individual determinants of intrinsic work motivation, emotional exhaustion and turnover intention". Maastricht:Universidade de Maastricht. PhD Dissertation.

Houkes, I., Janssen, P.P.M., de Jonge, J., \& Nijhuis, A. (2001). Specific relationships between work characteristics and intrinsic work motivation, burnout and turnover intention: A multi-sample analysis. European Journal of Work and Organizational Psychology, Vol.10. 1-23. http://dx.doi.org/10.1080/13594320042000007 
Huselid, M., Jackson, S. \& Schuler, R. (1997). Technical and Strategic Human Resource Management Effectiveness as Determinants of Firm Performance. Academy of Management Journal, Vol. 40, 171-188. http://dx.doi.org/10.2307/257025

Hyvonen, J. (2007). Strategy, performance measurement techniques and information technology of the firm and their links to organizational performance. Management Accounting Research, Vol. 18, 343-366. http://dx.doi.org/10.1016/j.mar.2007.02.001

Katzell, R. A., Thompson, D.E. (1990). Work motivation: theory and practice. AmericanPsychologist, Vol. 45, 144153. http://dx.doi.org/10.1037/0003-066X.45.2.144

Kellerman, B. (2007). What every leader needs to know about followers. Harvard Business Review, Vol.85, 84-91.

Kerr, N. L., \& Tindale, R. S. (2004). Group performance and decision making. Annual Review of Psychology, Vol. 55, 623-655. http://dx.doi.org/10.1146/annurev.psych.55.090902.142009

Lawler, E.E. (1994). Motivation in work Organizations. San Francisco: Jossey-Bass Publishers.

Lewis, P.S., Goodman, S.H. \& Fandt, P.M. (1995). Management: Challenges in the $21^{\text {st }}$ Century. New York: West Publishing Company.

Lunenburg, F.C. (2011). Self-Efficacy in the Workplace:Implications for Motivation and Performance, International Journal of Management, Business, and Administration, Vol.14, 1-22.

Mahal, P. (2009). Organizational culture and organizational climate as a determination of motivation. The IUP Journal of Management Research, Vol.8, 38-51.

Mehta, R. Dubinsky, A.J. \& Anderson, R.E. (2003). Leadership style, motivation and performance in international marketing channels: an empirical investigation of the USA, Finland \&Poland. European Journal of Marketing, Vol. 37, 50-85. http://dx.doi.org/10.1108/03090560310453939

Meyer, J.P. \& Allen, N.J. (1997). Commitment in the Workplace; theory, Research and application, Ca: Thousand Oakes.

Michaels, E., Handfield-Jones, H., \& Axelrod, B. (2001). The War for Talent. Boston, MA: Harvard Business Review Press.

Neves, J. (2002). "Gestão de recursos humanos: evolução do problema em termos dos conceitos e das práticas". In Caetano, A. \& Vala, J. (Org.) (pp. 3-30). Gestão de Recursos Humanos. Lisboa: RH Editora.

Neves, J. (2011). Aptidões individuais e teorias motivacionais. In Ferreira, C., Neves, J. \& Caetano, A. (Orgs.) (pp. 289-316). Manual de Psicossociologia das Organizações. Lisboa: Escolar Editora.

Nunnally, J.C. (1978). Psychometric theory. (2nd ed.), New York: McGraw Hill.

Parker, S.K., Wall, T.D., \& Cordery, J. (2001). Future work design research and practice: Towards an elaborated model of work design. [Invited contribution to Future of Work Special Issue], Journal of Occupational and Organizational Psychology, Vol. 74, 413-440. http://dx.doi.org/10.1348/096317901167460

Patchen, M. (1970). Participation, achievement, and involvement on the job. Engelwood Cliffs:Prentice-Hall.

Pina e Cunha, M., Rêgo, A., Campos E Cunha, R., Cabral-Cardoso, C., Marques, C., \& Gomes, J. (2010). Manual de Gestão de Pessoas e do Capital Humano $2^{\mathrm{a}}$ Edição. Lisboa: Edições Sílabo.

Podsakoff, P., Mackenzie, S., Lee, J., \& Podsakoff, N. (2003). Common Method Biases in Behavioral Research: A Critical Review of the Literature and Recommended Remedies. Journal of Applied Psychology, Vol. 88, 879-903. http://dx.doi.org/10.1037/0021-9010.88.5.879

Preacher, K. J., Rucker, D. D., \& Hayes, A. F. (2007). Addressing moderated mediation hypotheses: Theory, methods, and prescriptions. Multivariate Behavioral Research, Vol. 42, 185-227. http://dx.doi.org/10.1080/00273170701341316

Rose, C.R, \& Kumar. N. (2006). The Influence of Organizational and Human Resource Strategies on Performance. Performance Improvement Journal, Vol. 45, 18-24. http://dx.doi.org/10.1002/pfi.2006.4930450406

Rotenberry, P.F., \& Moberg, P.J. (2007). Assessing the impact of job involvement on performance. Management Research News,30, 203-215. http://dx.doi.org/10.1108/01409170710733278

Rousseau, D.M. (1995). Psychological contracts in organizations: Understanding written and unwritten agreements. Thousand Oaks, CA: Sage Publications. 
Scholl, R. W. (2002). Leadership style. Kingston: University of Rhode Island.

Sharbrough, W. (2006). Motivating language in industry. Journal of Business Communication, Vol. 43, 322-343. http://dx.doi.org/10.1177/0021943606291712

Shore, L. M., \& Tetrick, L. E. (1994). The psychological contract as an explanatory framework in the employment relationship. In Cooper, C. and Rousseau, D. (Eds.), Trends in Organizational Behavior, Vol. 1, 91-109.

Shore, L. \& Shore, T. (1995). Perceived organizational support and organizational justice, in R. Cronpanzano e K. Kacmar (Eds.), Organizational politics, justice, and support:managing social climate at work. Westport, CT: Quorum Press.

Silverman, L. (2006). How do you keep the right people on the bus? Journal of Quality \& Participation. Vol. 29, $11-15$.

Simms, J. (2007). Beyond the fringe. People Management.Vol. 13, 14-15.

Sobel, M. E. (1982). "Asymptotic confidence intervals for indirect effects in structural equation models". In S Leinhardt (Ed.), Sociological Methodology 1982 (pp. 290-312). Washington, DC: American Sociological Association.

Stavrou, E.T. and Brewster, C. (2005). The configurational approach to linking strategic human resource management bundles with business performance: Myth or reality? Management Revue, Vol. 16, 186-201.

Stipek, D. J. (1996). Motivation and instruction. In D. C. Berliner \& R. C. Calfee (Eds.), Handbook of educational psychology (pp. 85-113). New York: Macmillan.

Storey, J (Ed). (1995). Human Resource Management a Critical Text; RoutledgeCh 1, 2.

Thom, N. and Zaugg, R. J. (2004). Nachhaltiges und innovativesPersonalmanagement: Spitzengruppenbefragung in europäischenUnternehmungen und Institutionen, in E. J. Schwarz: Nachhaltiges Innovations management, Wiesbaden: Gabler, 217-245.

Thibaut, J. \& Walker, L. (1975). Procedural justice: A psychological analysis. Hillsdale, NJ: Lawrence Erlbaum Associates.

Tremblay, M., Sire, B., \& Balkin, D. B. (2000). The role of organizational justice in pay and employee benefit satisfaction and its effects and work attitudes. Organization Management, Vol. 25, 269-290.

Turner, J.C. (1995). The influence of classroom contexts on young children's motivation for literacy. Reading Research Quarterly, Vol. 30, 410-441. http://dx.doi.org/10.2307/747624

Ulrich, D. (1998). A new mandate for human resources. Harvard Business Review, 124-134.

Vroom. (1964). Work and Motivation. New York: Wiley.

Wright, P.M., Gardner, T.M., Moynihan, L.M., \& Allen, M.R. (2005). The relationship between HR practices and firm performance: Examining casual order, Personnel Psichology, Vol. 58, 409-446. http://dx.doi.org/10.1111/j.1744-6570.2005.00487.x

Wright, P.M., Rowland, K. \& Ferris, G. (1990). Perspectives on human resource management.In G. Ferris, K. Rowland and R. Buckley (Eds.) Human Resources Management:Perspectives and Issues, 4-16.

Wright, P.M. \& Snell, S.A. (2005). Partner or Guardian? HR's Challenge in Balancing Value and Values. Human Resource Management, Vol. 44, pp. 177-182. http://dx.doi.org/10.1002/hrm.20061

\section{Notes}

Note 1. Due to a parsimony principle of critical analysis, and to the purposes of this study in particular, the analysis of the literature review will only consider the need-base and the process-based perspectives concerning the study of motivation using the above mentioned Motivational Model's Taxonomy.

Note 2. All previous tests for validating the following regression models were fulfilled, namely: linearity of the study phenomenon; randomized residual variables with null expected value; inexistence of multicolinearity; homocedasticity; normal distribution of the randomized variables; independency of the residual randomized variables.

Note 3. please see Preacher, Rucher and Hayes (2007) for additional information regarding the expected effects of a moderated-mediation model. 